\title{
A hazai közlekedési rendszer védelmének, biztonságának fontossága a védelmi igazgatás szemszögéböl
}

\author{
The Importance of the Protection and Security \\ of the Domestic Transport System from the Point \\ of View of Defence Administration
}

\begin{abstract}
Absztrakt
A mai fejlett világban élö ember számára a közlekedés a mindennapok része, általános, természetes elvárás, hogy minél rövidebb idö alatt, minél egyszerübben eljussunk akár a világ távoli pontjaira is. A közlekedés stratégiai fontosságú a társadalmak életében, így egy ország teljes körü védelmének összehangolását és koordinálását ellátó védelmi igazgatás hatékony, gyors, szervezett feladatellátásához is nélkülözhetetlen a közlekedési rendszer elemeinek és infrastruktúrájának folyamatos müködőképessége.

A szerzö ebben a cikkben arra vállalkozott, hogy megvizsgálja az állam müködése szempontjából két kulcsfontosságú rendszer, a védelmi igazgatás és a közlekedés rendszerének alaprendeltetését, legfontosabb jellemzöit, bemutassa a két rendszer közötti kapcsolódási pontokat. Célja azon állítás igazolása, hogy az állam normál, mindennapi müködésétöl eltérö rendkivüli helyzetekben a védelmi igazgatás csak egy müködőképes közlekedési rendszer igénybevételével képes hatékonyan, gyorsan és eredményesen a feladatait ellátni.
\end{abstract}

Kulcsszavak: közlekedés, közlekedési alrendszerek, nemzeti létfontosságú rendszerelem, védelmi igazgatás, rendkivüli helyzetek 


\section{Abstract}

For people living in today's developed world, where transport is a part of everyday life, it is a general and natural expectation to reach even the most remote parts of the world as simple and fast as possible. Transportation is strategically important in the life of societies, so the ability of continuous operation of the elements and infrastructure of the transport system is essential for the efficient, fast and organised task management of the defence administration, which harmonises and coordinates the full protection of a state.

In this article, the author undertook to examine the basic functions and key characteristics of two key systems for the operation of the state, such as the defence administration and the transport system, and to present the interfaces between the two of them. Her purpose is to justify the assertion that in emergency situations which differ from the normal day-to-day operation of the state, defence management can only perform its functions effectively, quickly and efficiently by using a functioning transport system.

Keywords: transport, transport subsystems, national vital component, defence management, emergency situations

\section{Bevezetés}

A 20. század végétől kibontakozó globalizáció egyre nagyobb mértékü és egyre több területre begyűrűző térnyerésének egyik következményeként értékelhető a fizikai távolságok eltűnése. Globálisan általánossá vált a helyváltoztatás igénye, azaz, hogy a személyek és áruk bővülő köre mind nagyobb távolságokra, a lehető legrövidebb időn belül jusson el. Egy adott ország életében mindig is fontos szerepet betöltő közlekedés szerepe ezáltal az egyes társadalmak kulcsfontosságú tényezőjévé vált.

„Az elmúlt évszázad háborúinak, számtalan helyi fegyveres konfliktusának tapasztalatai, az egyre gyakrabban előforduló terrorcselekmények és természeti katasztrófák következményei egyértelműen alátámasztják a közlekedés stratégiai fontosságát és jelentőségét, amit a közlekedési hálózatokat és objektumait ért károk és veszteségek, az ezek következtében megjelenő ellátási-szállítási problémák is igazolnak."2

A közlekedési rendszer létfontosságú alrendszerei, valamint ezek rendszerelemei elengedhetetlenek az alapvető közszolgáltatási és védelmi feladatok végrehajtásához, végső soron ez a komplex rendszer az állam, a társadalom és a nemzetgazdaság müködőképességének egyik alappillérét képezi. Mindezt alátámasztja az is, hogy a közlekedési ágazat - azon belül a közúti, vasúti, légi, vízi közlekedési alágazatok és logisztikai központok - nemzeti létfontosságú rendszerelemnek minősül. ${ }^{3}$ Ezek közé azok a törvény alapján kijelölt létfontosságú rendszerelemek tartoznak, amelyek kiesésével egyes létfontosságú társadalmi feladatok folyamatos ellátása nem

Szászi Gábor: Nagyfolyami vasúti hidak, mint közlekedési létfontosságú rendszerelemek, in: Horváth Attila - Bányász Péter - Orbók Ákos (szerk.), Fejezetek a létfontosságú közlekedési rendszerelemek védelmének aktuális kérdéseiről, Nemzeti Közszolgálati Egyetem, Budapest, 2014, 27.

3 2012. évi CLXVI. törvény a létfontosságú rendszerek és létesítmények azonosításáról, kijelöléséről és védelméről 2. §-a, valamint 1. melléklete. 
biztosított, és ennek hiánya jelentős hatással lehet Magyarország gazdaságára, védelmére, a lakosság életére és biztonságára. ${ }^{4}$

A téma kutatása során abból a feltételezésböl indultam ki, hogy a védelmi igazgatás szemszögéből is fontos a Magyarországon esetlegesen előforduló rendkívüli helyzetek gyors, hatékony kezeléséhez a közlekedési rendszer, valamint a rendszer alrendszereinek és infrastruktúrájának müködőképessége.

A fentiek alapján ebben a cikkben megvizsgálom a közlekedés és a védelmi igazgatás rendszerének alapvető jellemzőit. Vizsgálom a két rendszer kapcsolódási pontjait, majd ezt a kapcsolatot bemutatom a védelmi igazgatás legfontosabb feladatcsoportjain keresztül, rávilágítva ezáltal arra, hogy az állam normál, mindennapi müködésének helyreálítása érdekében, a rendkívüli helyzetekre történő gyors és hatékony reagáláshoz a közlekedési rendszerelemek igénybevétele nélkülözhetetlen.

\section{A hazai közlekedési rendszer fogalma, alaprendeltetése és al- rendszereinek jellemzői}

A közlekedési rendszer fogalmát, értelmezését számos szakmai publikációban, szakkönyvben fellelhetjük. Szászi Gábor PhD-értekezésében ${ }^{5}$ a polgári és a katonai közlekedési rendszer kapcsolódási pontjait is vizsgálta, ami logikai alapot ad a közlekedési rendszer és a védelmi igazgatási feladatok kapcsolatának bemutatásához is. A számos fogalmi meghatározás közül publikációm szempontjából az alábbit tekintem a legátfogóbbnak:

„A közlekedés személyek, dolgok, gondolatok (információk) speciális technikai eszközök igénybevételével lebonyolított tömeges, rendszeres, szervezett helyváltoztatása."6

A közlekedés lényege a helyváltoztatás, aminek megvalósulásához a tömeges folyamatok bizonyos szintủ szervezettségére, tudatosságra és célirányultságra van szükség. A közlekedés komplex rendszerének elemei számtalan szempont alapján csoportosíthatók, mint például a közlekedési tevékenység végrehajtása, a szervezetiintézményi rend, illetve a közlekedés környezeti és technikai jellemzői szerinti ágazati besorolás szerint. A közlekedési nemzetgazdasági ág belső ágazati rendszerén belül alapvetően két csoportot különböztethetünk meg, a szállítás - amely élölények, tárgyak továbbítására szolgál - és a hírközlés - amely a nem testet öltött dolgok (hírek, információk) helyváltoztatását végzi - ágazatát. A szállítási ágazaton belül mind a személy-, mind az áruszállítás vonatkozásában ismeretes a környezeti szempontú szárazföldi, vízi, légi közlekedés különbségtétel. ${ }^{7}$

A legáltalánosabb kategorizálás a közlekedés módjai szerinti csoportosítás, amely alapján a közúti, vasúti, vízi és légi közlekedést, mint a négy fö alágazatot, valamint

2012. évi CLXVI. törvény 1. § g) pontja.

Szászi Gábor: A vasúti hálózati infrastruktúrával szemben támasztott újszerü védelmi követelmények kutatása, a továbbfejlesztés feltételrendszerének vizsgálata, Doktori (PhD) értekezés, Nemzeti Közszolgálati Egyetem, 2013, 19-26. A közlekedés fogalma, https://ko.sze.hu/catdoc/list/cat/7086/id/7106/m/4974 (Letöltve: 2019. 04. 30.)

A közlekedési rendszer csoportosítása, https://ko.sze.hu/catdoc/list/cat/7086/id/7106/m/4974 (Letöltve: 2019. 04. 30.) 
a városi közlekedést, a csővezetékes szállítást, továbbá a hírközlés és informatika alágazatokat különböztethetjük meg. ${ }^{8}$

Az egyes alágazatokon belül további kategorizálások lehetségesek, így például a forgalom jellege alapján belföldi és nemzetközi, az igénybevehetőség szerint közforgalmú (bárki által igénybe vehető), korlátozott közforgalmú és nem közforgalmú (egyéni, közületi) közlekedést különböztethetünk meg. ${ }^{9} \mathrm{~A}$ közlekedési rendszer további csoportosítását az 1. táblázat tartalmazza.

1. táblázat: A közlekedési rendszerek csoportosítása

\begin{tabular}{|c|c|c|c|c|}
\hline $\begin{array}{l}\text { Csoportosítási } \\
\text { szempontok }\end{array}$ & \multicolumn{4}{|c|}{ Csoportok } \\
\hline Szállítás tárgya & \multicolumn{2}{|c|}{ személyközlekedés } & \multicolumn{2}{|c|}{ áruszállítás } \\
\hline Szervezési forma & \multicolumn{2}{|c|}{ egyéni közlekedés } & \multicolumn{2}{|c|}{$\begin{array}{l}\text { közforgalmú (tömeg, közösségi) } \\
\text { közlekedés }\end{array}$} \\
\hline \multirow{2}{*}{ Közlekedési pálya } & közúti & vasúti & légi & vízi \\
\hline & szállítószalag & mozgójárda & vezeték & csővezeték \\
\hline Mozgási folyamat & \multicolumn{2}{|c|}{ mozgó forgalom } & \multicolumn{2}{|c|}{ álló forgalom } \\
\hline Távolsági tartomány & rövid távú (helyi) & $\begin{array}{c}\text { közepes távú } \\
\text { (regionális) }\end{array}$ & \multicolumn{2}{|c|}{ távolsági (helyközi) } \\
\hline $\begin{array}{c}\text { Település vonatkozá- } \\
\text { sában }\end{array}$ & belső forgalom & $\begin{array}{l}\text { induló- és } \\
\text { célforgalom }\end{array}$ & \multicolumn{2}{|c|}{ átmenő forgalom } \\
\hline \multirow{2}{*}{$\begin{array}{l}\text { Helyváltoztatási cél/ } \\
\text { úticél }\end{array}$} & lakóhely & hivatás & $\begin{array}{l}\text { szolgálati } \\
\text { tevékenység }\end{array}$ & képzés \\
\hline & bevásárlás/ellátás & szolgáltatás & $\begin{array}{l}\text { szabadidő, } \\
\text { pihenés }\end{array}$ & gazdaság stb. \\
\hline \multirow{5}{*}{$\begin{array}{c}\text { Közlekedési/szállító- } \\
\text { eszközök }\end{array}$} & gyalog & kerékpár & motorkerékpár & $\begin{array}{l}\text { személygépkocsi, } \\
\text { egyéb jármü }\end{array}$ \\
\hline & autóbusz & trolibusz & villamos & városi vasút \\
\hline & elővárosi vasút & távolsági vasút & földalatti vasút & kötélvasút \\
\hline & hegyi vasút & hajó & \multicolumn{2}{|c|}{ repülőgép } \\
\hline & lift & mozgólépcső & \multicolumn{2}{|c|}{ mozgójárda } \\
\hline
\end{tabular}

Forrás: Kövesné et al. (2010): i. m. 70

A közlekedés technikai rendszerei közé sorolhatók a pályák, a járművek, az energiaellátási és hajtási rendszerek, valamint a kiszolgáló létesítmények. ${ }^{10}$

Kövesné Gilicze Éva et al.: Közlekedés és társadalom, BME, Budapest, 2010, 27.

9 A közlekedési alágazatok kategorizálási lehetőségei, https://ko.sze.hu/catdoc/list/cat/7086/id/7106/m/4974 (Letöltve: 2019. 04. 30.)

10 Kövesné et al. (2010): i. m. 28. 


\section{A közlekedési alágazatok legföbb jellemzöi}

A közlekedési alágazatok jellemzőinek bemutatását azért tartom szükségesnek, mert ennek ismeretében lehetséges csak azt vizsgálni, hogy mely alágazatok tekinthetők kiemelt jelentőségűnek a védelmi igazgatási feladatok megoldása során. Az egyes közlekedési alágazatok jellemzői az alábbiak: ${ }^{11}$

\section{A vasúti közlekedés}

Elönyei:

- nagylétszámú, kis- és nagytávolságú személyszállítás a hivatás-, a távolsági és a nemzetközi forgalomban;

- nagytömegủ közép- és nagytávolságú áruszállítás; teljesítőképes, gazdaságos és környezetbarátabb üzem;

- átrakás nélküli iparvágány-forgalom;

- magas üzemi biztonság;

- a vasút a kombinált áruszállítás fö hordozója.

Hátrányai:

- alacsony szolgáltatási színvonal mind a személy-, mind az áruszállításban, aminek növelése csak hosszabb távon, jelentős beruházásokkal lehetséges;

- hatóságilag szabályozott díjszabás, korlátozott versenyképesség;

- iparvágányok nélküli gyűjtő- és terítőfuvarozás szükséges;

- nagy az infrastruktúra-igény, ami nem mindig használható ki;

- az alacsony informatikai szint a személy- és áruszállításban nem teszi lehetővé a szolgáltatások minőségének emelését;

- a technikai és a technológiai színvonal elmaradott, és ez csak jelentős élömunka-ráfordítással pótolható.

\section{A közúti közlekedés}

Elönyei:

- kis létszámú kis és közepes távolságú személyszállítás;

- kis tömegü kis és közepes távolságú áruszállítás;

- rugalmas tarifapolitika, versenyképesség;

- magas szolgáltatási minőség;

- terítő- és gyűjtőforgalom a kereskedelmi, szolgáltatási szférában;

- ráhordó és elszállító szerepkör más ágazatokhoz kapcsolódva (vasút, légi közlekedés);

- jelentős részesedés az üzemi szállításokban;

- a szállítási célpontok jó megközelítése;

11 Kövesné et al. (2010): i. m. 33-35. 
- az igényekhez igazodva sokféle típusú és teherbírású jármü;

- bárki részt vehet benne.

Hátrányai:

- magas környezetszennyezés;

- nagy a fajlagos energiafelhasználás;

- kedvezőtlen a rakott és az üres futás aránya;

- alacsony biztonsági szint;

- a kimerülő útpálya-kapacitások csak jelentős beruházások révén növelhetők.

\section{A vízi közlekedés}

Elönyei:

- a vízi utakon jelentős szabad kapacitások állnak rendelkezésre;

- alacsony tarifaszint;

- kis fajlagos energiafelhasználás;

- magas biztonság.

Hátrányai:

- a vízi utak és a kikötők meghatározzák a hajózás mozgásterét;

- alacsony a rendelkezésre állás (vízszint, fagy);

- átrakási kényszerek a fuvarozás közbeni vízszintváltozásnál;

- ráhordó és elszállító szállítás szükséges.

\section{A légi közlekedés}

Elönyei:

- nagytávolságú nemzetközi és interkontinentális személyszállítás;

- hosszabb útvonalakon gyors utazási sebesség;

- rövid eljutási idő;

- magas szolgáltatási színvonal.

Hátrányai:

- környezetszennyezés a repülőterek esetében (zajhatások);

- jelentös fajlagos üzemanyag-felhasználás;

- fokozott érzékenység a szélsőséges időjárásra.

A közlekedés fogalmát, a közlekedési rendszer felépítését, különböző csoportosításait, a közlekedési alágazatok legfőbb jellemzőit vizsgálva megállapítható, hogy a közlekedés rendszere a mai életviszonyokhoz igazodóan egy rendkívüli komplex, bonyolult rendszer, védelme, müködőképességének fenntartása az élet minden területén, minden ember számára létfontosságú. Az is látható, hogy az egyes alágazatok alkalmazási 
lehetőségei eltérőek, illetve a technológiai sajátosságok okán a védelmi igazgatási feladatok megoldása során csak bizonyos alágazatok alkalmazhatók hatékonyan.

\section{A védelmi igazgatás fogalma, alaprendeltetése, müködési rendszere, alapvető feladatcsoportjai}

A honvédelemről és a Magyar Honvédségröl, valamint a különleges jogrendben bevezethető intézkedésekről szóló 2011. évi CXIII. törvény (Hvt.) 80. §32. pontja - az értelmező rendelkezések között - határozza meg a védelmi igazgatás fogalmát az alábbiak szerint:

„A közigazgatás részét képező feladat- és szervezeti rendszer, amely a Kormány-a honvédelemért felelős miniszter útján gyakorolt - irányítása mellett a Magyarországot veszélyeztető fenyegetésekkel és támadásokkal szemben azállam feladatainak megvalósítására létrehozott, valamint egyes védelmi feladatok ellátására kijelölt közigazgatási szervek által végzett tervező, végrehajtó, rendelkező tevékenység."12

Szervezeti rendszerét vizsgálva megállapítható, hogy az a közigazgatás szervezetrendszerén - azon belül az államigazgatás alrendszerének szervezetrendszerén - belül valósul meg, centrális irányítás és hierarchikus felépítés mellett, azzal a megjegyzéssel, hogy a rendszer legalsó szintjén, települési szinten a feladatokat az önkormányzati igazgatás képviselőjeként, de a védelmi igazgatás rendszerébe integráltan a polgármester látja el. A védelmi igazgatás felépítése a 1. ábrán látható.

Feladatrendszerét tekintve a védelmi igazgatás kiterjed az ország teljes körü védelmére, hiszen a különböző rendkívüli helyzetekben vagy ezek veszélye esetén magában foglalja a honvédelmi, polgári védelmi, rendvédelmi, védelemgazdasági, lakosságellátási feladatok tervezését, szervezését, végrehajtását, valamint a rendkivüli helyzetekre történő felkészülést.

12 A korábbi szabályozás szerint a védelmi igazgatás definíciója a következő volt:„A közigazgatás részét képező feladat- és szervezeti rendszer, amely az állam védelmi feladatainak megvalósítására létrehozott, valamint e feladatra kijelölt közigazgatási szervek által végzett végrehajtó, rendelkező tevékenység; magában foglalja a különleges jogrendre történő felkészülést, továbbá az említett időszakok és helyzetek honvédelmi, polgári védelmi, rendvédelmi, védelemgazdasági, lakosság-ellátási feladatainak tervezésére, szervezésére, a feladatok végrehajtására irányuló állami tevékenységek összességét." A honvédelmi törvény végrehajtási rendelete, a 290/2011. (XII. 22.) Korm. rendelet 1. §n) pontjában rögzített meghatározás a felmerülő feladatcsoportokat taxatíve felsorolta, ám ezek tervezését, szervezését, végrehajtását, illetve az ezekre a feladatokra történő felkészülést a különleges jogrend időszakához kötötte. 


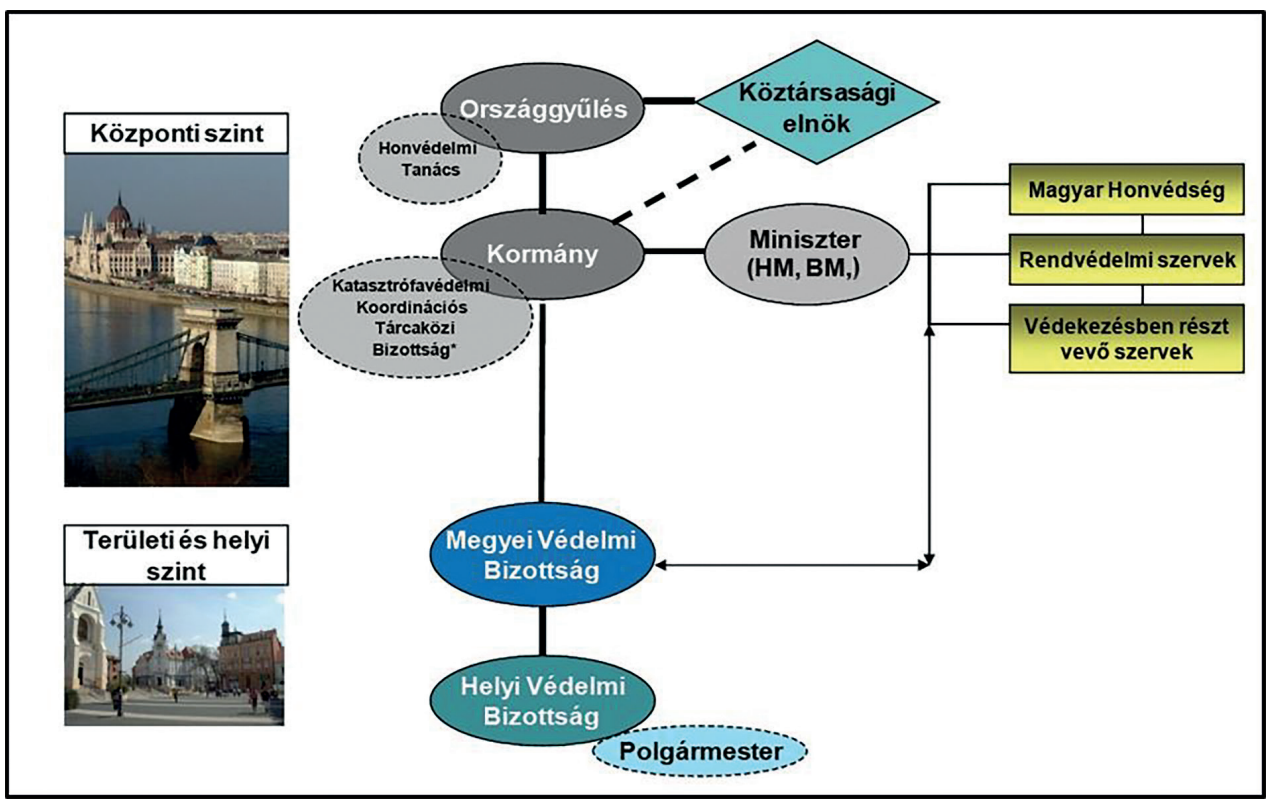

1. ábra: A védelmi igazgatás struktúrája

Forrás: Baán Mihály et al:: Magyarország védelmi igazgatása a közigazgatás új környezetében, Zrínyi Kiadó, Budapest, 2014, 54. www.kormany.hu/download/9/68/20000/Magyarorszag_Vedelmi_lgazgatasa_a_Kozigazgatas_Uj_Kornyezeteben_2014_n.pdf\#!DocumentBrowse (Letöltve: 2019. 04. 24.)

Az új szabályozás megítélésem szerint a korábbi meghatározáshoz képest nagymértékben bővítette a fogalmat, egyrészt a védelmi igazgatás szereplői számának növekedése, másrészt a védelmi igazgatás tágabban értelmezhető feladatrendszere tekintetében. Ez utóbbit olyan formában, hogy a védelmi igazgatás szereplői már nemcsak elsősorban a különleges jogrend egyes esetköreihez kapcsolódóan, valamint az ezen esetkörökkel kapcsolatos felkészülés keretében, hanem bármely, Magyarországot veszélyeztető fenyegetéssel és támadással szemben jogosultak eljárni. ${ }^{13}$ Álláspontom szerint a rendszer aktiválását igényli az Alaptörvényben és a sarkalatos törvényekben ${ }^{14}$

13 A védelmi igazgatás fogalmában bekövetkezett módosulás indokolása. A 2011. évi CXIII. törvény (Hvt.) 80. § 32. pontja szerint a Magyarországot veszélyeztető fenyegetésekkel és támadásokkal szemben lép müködésbe a védelmi igazgatás rendszere, a módosítás oka az indokolás szerint az, hogy a szabályozás az Észak-atlanti Szerződés Szervezetének azon döntéséhez igazítsa az érintett fogalmat, amely folytán a hadszínterek között megjelenítette a kiberteret is, vagyis a katonai védelem terén jelentős hangsúlyt adott a kinetikus erő alkalmazhatóságának kérdése mellett a nem kinetikus, technikai alapú tevékenységeknek is. www.parlament.hu/irom41/03291/03291.pdf (Letöltve: 2019. 04. 25.)

14 2011. évi CXIII. törvény a honvédelemröl és a Magyar Honvédségröl, valamint a különleges jogrendben bevezethető intézkedésekröl.; 2011. évi CXXVIII. törvény a katasztrófavédelemröl és a hozzá kapcsolódó egyes törvények módosításáról. 
meghatározott különleges jogrendi esetkörök, ${ }^{15}$ egyéb, különbözö törvényekben szabályozott esetek ${ }^{16}$ bekövetkezésén túl minden olyan a jövőben potenciálisan elöforduló, jelenleg talán még nem is ismert rendkívüli helyzet bekövetkezése vagy annak valamilyen szintű veszélye, amely az országot, annak biztonságát, működőképességét, az állampolgárok életét, egészségét, a környezetet, az alapvető anyagi javakat súlyos mértékben sérti vagy veszélyezteti.

A védelmi igazgatás feladatai sokféle szempont szerint csoportosithatók. A hatályos szabályozás ${ }^{17}$ a végrehajtás szintjei szerint határozza meg azokat az irányító (Kormány, a minisztériumok), az igazgatási feladatokat ellátó (a megyei és helyi védelmi bizottságok, a védelmi bizottságok elnökei, a polgármesterek) és a végrehajtó szervezetekre (Magyar Honvédség, rendvédelmi, katasztrófavédelmi szervek, egyéb közremüködők) vonatkoztatva.

Ennek megfelelően a Kormány a honvédelemért felelős miniszter útján irányítja a megyei védelmi bizottságok honvédelmi feladatainak végrehajtását; megszervezi a katasztrófák elleni védekezés irányítását és a végrehajtás összehangolását, a tervezés kormányszintü feladatainak végrehajtását, a katasztrófák következményeinek felszámolására való felkészülés, a megelőzés, a végrehajtás és a helyreállítás feladatainak tárcák közötti koordinációját.

A megyei védelmi bizottság a honvédelmi igazgatási jogkörében irányítja a helyi védelmi bizottságokat, a polgármesterek honvédelmi tevékenységét, ellátja a hatáskörébe utalt, a fegyveres összeütközések időszakában végrehajtandó polgári védelmi feladatokat, egyedi határozattal megállapítja a honvédelemben közremúködő szervek részére a honvédelmi felkészítés követelményeit és feladatait, összehangolja azok végrehajtását stb.

A megyei, illetve a helyi védelmi bizottság az illetékességi területén összehangolja a katasztrófák elleni védekezésben közremüködő szervek katasztrófavédelemmel kapcsolatos feladatainak ellátását és az arra való felkészülést, de a megyei védelmi bizottság elnöke felel például a megye szintü honvédelmi feladatok összehangolásáért is. A helyi védelmi bizottság elnöke meghatározza a katasztrófák elleni védekezés helyi feladatait, ellenőrzi azok végrehajtását, illetve elrendeli a települési polgári védelmi erők bevonását, felel a helyi szintü honvédelmi feladatok összehangolásáért.

$A$ védelmi igazgatás fogalmát, alaprendeltetését, kapcsolatrendszerét, valamint a szervezeti rendszert elemezve látható, hogy egy rendkívül komplex, összetett rendszerröl van szó, amely az ország teljes körü védelmét hivatott összehangolni és koordinálni. Kapcsolatrendszere közül ki kell emelni a közlekedési rendszerrel összefüggő viszonyát, mivel védelmi feladatainak végrehajtása nagyban függ annak biztonságától, működőképességétől.

15 Rendkívüli állapot, szükségállapot, megelőző védelmi helyzet, terrorveszélyhelyzet, váratlan külső támadás, veszélyhelyzet.

16 A katasztrófavédelmi törvényben szabályozott katasztrófaveszély, a honvédelmi törvényben szabályozott honvédelmi veszélyhelyzet, az egészségügyi törvényben rögzített egészségügyi válsághelyzet, valamint a menedékjogi törvényben szabályozott tömeges bevándorlás okozta válsághelyzet.

17 2011. évi CXIII. törvény; 290/2011. (XII. 22.) Korm. rendelet a honvédelemröl és a Magyar Honvédségröl, valamint a különleges jogrendben bevezethető intézkedésekről szóló 2011. évi CXIII. törvény egyes rendelkezéseinek végrehajtásáról.; 2011. évi CXXVIII. törvény; 234/2011. (XI. 10.) Korm. rendelet a katasztrófavédelemről és a hozzá kapcsolódó egyes törvények módosításáról szóló 2011. évi CXXVIII. törvény végrehajtásáról. 


\section{A védelmi igazgatási feladatok és a hazai közlekedési rendszer közötti lehetséges kapcsolat, a múködés biztonságának fon- tossága}

A közlekedési és a szállítási feladatok életünk minden területén jelen vannak, átszövik a társadalom egészét, nemcsak a közigazgatás, a gazdasági élet és a lakosság ellátásához nélkülözhetetlenek, de a közlekedési rendszer igénybevétele nélkül a rendkívüli helyzetek kezelése, az ehhez szükséges feladatok ellátása - amely a védelmi igazgatás rendszerében történik - sem képzelhető el. Mindebből adódóan a közlekedési rendszer múködőképességének biztosítása, az alrendszerek elemeinek, infrastruktúráinak védelme rendkívül fontos a védelmi igazgatás szemszögéből is. Ebből következik, hogy a közlekedési rendszer alrendszerei, valamint a védelmi igazgatási feladatok ellátása között szoros kapcsolat mutatható ki. A védelmi igazgatási feladatok védelmi területenként az alábbiak szerint csoportosíthatók:

- az ország védelmével, függetlenségének biztosításával összefüggő honvédelmi feladatok csoportja

- a védelemgazdasággal kapcsolatos feladatok csoportja

- a katasztrófavédelmi feladatok csoportja

- a rendvédelmi típusú feladatok csoportja (terrortámadás vagy annak jelentős és közvetlen veszélye esetén, tömeges bevándorlás okozta válsághelyzetben).

Az alábbiakban ismertetem a különböző feladatcsoportokból azokat a feladatokat, amelyek végrehajtása nagyban függ a közlekedési rendszer állapotától.

\section{A honvédelmi feladatok csoportja}

Ebbe a feladatcsoportba az ország védelmével, függetlenségének biztosításával összefüggő katonai és polgári védelmi feladatok tartoznak, amelyek polgári és államigazgatási oldalról történő összehangolása, koordinálása a védelmi igazgatás hatáskörébe tartozik. Ezek közül a legfontosabbak, amelyek végrehajtása kapcsolatban van a közlekedési rendszerrel:

- a katonai alakulatok felvonulásának, a haditechnikai anyagok és eszközök szállításának, célterületre történő eljuttatásának segítése, a feltételek kialakításának és biztosításának koordinálása;

- a befogadó nemzeti támogatás keretében a hazánkba érkező szövetséges katonai alakulatok közlekedési és szállítási feladatainak végrehajtásához szükséges feltételek megteremtésével, biztosításával összefüggö, a védelmi igazgatás hatáskörébe tartozó feladatok;

- a hadműveleti területről kivont lakosság és anyagi javak szervezett elszállításának szervezési és koordinációs feladatai;

- a menekülő lakosság közlekedésének szabályozása, az ezzel összefüggő szállítások szervezésének és a feltételek biztosításának koordinálása; 
- a lakosság háborús ellátásával, az életfeltételek biztosításával kapcsolatos közlekedési és szállítási feltételek megszervezése és biztosításának koordinálása;

- a polgári védelmi szervezetek háborús kárterületre történő összevonásához, ${ }^{18}$ a mentési feladatok végrehajtásához szükséges közlekedési és szállítási feltételek kialakításának szervezése és koordinálása.

Mindezen feladatok megvalósításához fontos, hogy a szükséges szállítókapacitás és a szállítóeszközök mindig rendelkezésre álljanak és müködőképesek legyenek, továbbá gondoskodni kell a létfontosságú szállítási útvonalak és rendszerelemek védelméről, biztonságáról, müködőképességéröl és megfelelő müszaki állapotáról.

\section{A védelemgazdasággal kapcsolatos feladatok csoportja}

A nemzetgazdaság részét képező védelemgazdaság alapvető rendeltetése a honvédelmi célú erőforrások összegyűjtése, azok rendeltetésszerű felhasználása, azaz védelmi képességgé történő átalakítása. ${ }^{19}$

„A védelmi célú tartalékolás az államot és a társadalmat fenyegető, elöre nem látható veszélyhelyzetek kezelésében, az adott szituációk felszámolásában kulcsszerepet játszó, úgynevezett elsődleges beavatkozó (honvédelmi és rendvédelmi) szervek, illetve speciális feladatkörre létrejött civil szervezetek működését, a lakosság ellátását, valamint a gazdaság válsághelyzeti müködőképességének fenntartását biztosítja." ${ }^{20}$

A védelemgazdasági feladatok végrehajtása - ide értve a gazdasági és anyagi szolgáltatási kötelezettség, a meghagyás területeit - szintén kötődik a közlekedési rendszerhez.

A védelmi igazgatás egyes szereplői által elrendelt gazdasági- és anyagi szolgáltatáso ${ }^{21}$ igénybevétele esetén magánszemélyeknek, gazdálkodó szervezeteknek, vállalatoknak, üzemeknek, intézményeknek a honvédelmi feladatok végrehajtásához szükséges anyagai, technikai eszközei, gépjármüvei mozgósítása, összevonása érdekében, ahhoz, hogy ezek az anyagok, eszközök, gépjármüvek eljussanak a rendeltetési helyükre, szükség van a közlekedési rendszer alrendszereinek szállítási képességeire, mútárgyainak, technikai eszközeinek müködőképességére. Különösen igaz ez a közúti és vasúti közlekedésre és szállításra, az ezekkel kapcsolatos feladatok tervezését, szervezését és koordinálását a védelmi igazgatásnak kiemelten kell kezelni.

2011. évi CXIII. törvény 11. §.

19 Baán et al. (2014): i. m. 53.

20 Babos Tibor - Beregi Alexandra Lilla: A védelemgazdaság biztonságpolitikai összefüggései napjainkban, Hadmérnök, $12(2018 / 3)$ 351. www.hadmernok.hu/183_25_babos.pdf (Letöltve: 2019. 05. 13.)

21 2011. évi CXIII. törvény 13-15. §. 


\section{A katasztrófák elleni védekezéssel összefüggő feladatok cso- portja}

A védelmi igazgatás egyes katasztrófavédelemmel összefüggő feladatai, valamint a közlekedési rendszer között szintén kimutatható a honvédelmi feladatoknál tapasztalható kapcsolat. Ezek közül a legfontosabbak a következők:

- a polgári védelmi és a mentésben részt vevő más szervek, szervezetek, valamint a védekezéshez szükséges anyagok, eszközök, felszerelések kárterületre történő eljuttatásának segitése, a feltételek kialakitásának és biztosításának koordinálása;

- a kárterületröl kitelepített/kimenekített lakosság és anyagi javak biztonságos helyre történő elszállításának szervezése és koordinálása;22

- kitelepített/kimenekített lakosság ellátásával, életfeltételeinek biztosításával, valamint visszatelepítésével kapcsolatos közlekedési és szállítási feltételek szabályozásával, megszervezésével összefüggő feladatok koordinálása; ${ }^{23}$

- a kárterület rehabilitációjával, újjáépítésével kapcsolatos, a védelmi igazgatás hatáskörébe tartozó, közlekedéssel és szállítással összefüggő feladatok szervezése és koordinálása.

A fenti feladatok gyors és eredményes végrehajtását nagymértékben befolyásolja a közlekedési alrendszerek kapacitása, műszaki állapota, sérülékenysége, ezért fontos ezek védelmét kiemelten kezelni.

\section{A terrorizmussal és migrációval kapcsolatos feladatcsoport}

Egy esetleges terrortámadás vagy annak jelentős és közvetlen veszélye, valamint egy migrációs hullám bekövetkezése esetén a védelmi igazgatásnak is el kell látnia olyan közreműködői és koordinációs tevékenységet, amelyek között megtalálhatók a közlekedéssel és szállítással kapcsolatosak is. Például:

- a tömeges bevándorlás okozta válsághelyzet elrendelését követően a hatályos szabályozás alapján ${ }^{24}$ lehetőség van a válsághelyzet kezeléséhez, a feladatok ellátásához szükséges mértékben -állam vagy a helyi önkormányzat tulajdonosi joggyakorlásában vagy vagyonkezelésében, továbbá a többségi állami tulajdonban vagy önkormányzati tulajdonban lévő gazdasági társaságok tulajdonában álló - ingó és ingatlan vagyontárgyak ideiglenes igénybevételére. Az igénybe vett anyagok, technikai eszközök, gépjármüvek rendeltetési helyükre történő eljutása, eljuttatása a közlekedési rendszer alrendszereinek, mútárgyainak segítségével történhet. Az ezzel kapcsolatos tervezési, szervezési, koordinációs feladatokat a védelmi igazgatás végzi;

22 2011. évi CXXVIII. törvény 12. § (2) bek. g) pontja, 16. § d) pontja, 49. § (4) bek.; 234/2011. (XI. 10.) Korm. rendelet 1. § 3., 14., 15. pontja, 46-53. §, 77. § (2) bek. d) pontja.

23 234/2011. (XI. 10.) Korm. rendelet 1. § 3., 14., 15. pontja, 46-54. §, 77. § (2) bek. d) pontja.

24 2007. LXXX. törvény a menedékjogról 80/B. §. 
- szükség esetén a védelmi igazgatás részt vesz a migránsok gyüjtőpontok és szükségtáborok közötti szállításának megszervezésében;

- a gyűjtőpontokon, valamint a szükségtáborokban a beérkezettek ellátásával, alapvető szükségleteinek biztosításával kapcsolatos közlekedési és szállítási feltételek megszervezésében és biztosításának koordinálásában történő közremüködés szintén védelmi igazgatási feladat;

- terrortámadás esetén a mentési feladatok végrehajtásához szükséges közlekedési és szállítási feltételek kialakításának szervezése és koordinálása; a mentésben részt vevő szervek, szervezetek, valamint a védekezéshez szükséges anyagok, eszközök, felszerelések célterületre történő eljuttatásának segítése, a feltételek kialakításának és biztosításának koordinálása is a feladatai közé tartozhat;

- nagy pusztítással járó terrortámadás végrehajtását követően a célterület rehabilitációjával, újjáépítésével összefüggö, a védelmi igazgatás hatáskörébe tartozó, közlekedéssel és szállítással összefüggő feladatok szervezése és koordinálása is megjelenhet a feladatok között.

A fentiek jól mutatják, hogy a védelmi igazgatás rendszere és azáltal az ország védelme hogyan és milyen mértékben függ a közlekedési rendszer hálózatainak és objektumainak müködőképességétől, müszaki állapotától, kapacitásától, amelynek szerepe a rendkívüli helyzetekben - amikor az ország függetlensége, állampolgárainak élete, egészsége, anyagi javai kerülnek veszélybe - még inkább felértékelődik.

A közlekedési rendszer müködőképességét számos tényező befolyásolja és veszélyezteti. Így például, ha valamilyen, a védelmi igazgatás aktiválódását igénylő rendkívüli helyzet - háborús vagy polgárháborús esemény, terrortámadás vagy szélsőséges időjárás stb. - következtében a közlekedési alrendszerek valamely eleme vagy azok kiemeltnek tekinthető mütárgyai, nagy folyókat átszelő vasúti hidak, repülőterek, kikötők, vasúti pályaudvarok, hidak, alagutak, forgalomirányító-központok ${ }^{25}$ kerülnek veszélybe vagy sérülnek meg.

Napjainkban leginkább az egyre inkább szélsőségessé váló időjárási elemek, a csapadék, a hőmérséklet és a szél okozzák a legnagyobb kihívást, és egyre nagyobb mértékü károkat okoznak országszerte, sok esetben az adott területen megbénítják a közlekedést és az ellátást.

A nagy mennyiségben, nagy intenzitással lehullott hótömeg következtében kialakuló jegesedés, felfagyás károkat okoz az egyébként is sérülékeny úthálózatban. Az özönvízszerü esőzés dombvidéken és hegyvidéken rézsűomlást, burkolatkimosást, padkaleszakadásokat okozhat az úttesteken. A rendkívüli nagy mennyiségü csapadék árvizek kialakulásához vezethet. Az árvizek érzékenyen érintik a hazai vasúthálózatot, amelynek több mint 10\%-át árvízveszélyes vonalak képezik. Számos esetben árvízi töltésen halad a vasútvonal, így a töltés átázása a vasúti pálya elmozdulásához vezethet.

A magas hömérséklet hatására a közutak esetében nyomvályúk alakulhatnak ki a nagy és nehéz jármüvek súlya miatt, míg a vasúthálózat esetében a sínek kitágulhatnak, felpúposodhatnak. Az alacsony hömérséklet következtében pedig a fagyás - felengedési ciklusok gyakorisága, a jegesedés (felsővezeték-szakadáshoz vagy a sínek

25 Szászi (2014): i. m. 10., 27. 
melletti fák ágának letöréséhez, a fák kidőléséhez vezethet a rájuk nehezedő jég súlya miatt, amelyek a felsővezetékekre vagy a sínpályára dőlnek, esnek rá), a sínelfagyások, síntörések, a repedezés - kátyúsodás jelenthet gondot. ${ }^{26}$

A rendkívüli erősségü - 90 km/ óra feletti - szél következtében a kicsavart fák, különböző tárgyak, közúti reklám- és jelzőtáblák elmozdulva, leszakadva kerülhetnek az úttestekre, sínekre és ott akadályt képezhetnek, valamint a felsővezetékekben, jármüvekben sérüléseket okozhatnak.

Mindezek alapján megállapítható, hogy az időjárás szélsőséges megnyilvánulásai - főként, ha a különböző időjárási elemek együttesen jelentkeznek - a közlekedési infrastruktúrában gazdasági, társadalmi zavarokkal együtt járó károkat okozhatnak.

A másik, biztonságunkra potenciálisan leselkedő veszélyforrás a terrorizmus. Világszerte és Európában is az elmúlt évtizedben egyre gyakoribbá váltak a terrortámadások. Magyarországra a terrorizmus kapcsán jelenleg a leginkább jellemző a „tranzit-lét”, azonban egy esetlegesen bekövetkező terroristatámadással ${ }^{27}$ föként hazánk nemzetközi szerepvállalása kapcsán számolnunk kell. Az eddigi tapasztalatok rávilágítottak arra, hogy rendkívül széles az a kör, akik vagy amelyek terrorakciók célpontjaivá válhatnak. A forgalmas turisztikai látványosságokon, szállodákon, bevásárlóközpontokon, szórakozó- és vendéglátóhelyeken kívül a terrorizmus kiszámíthatatlansága folytán a közösségi közlekedés termináljai, a közlekedési hálózatok stratégiai fontosságúnak tekinthető műtárgyai, így repülőterek, kikötők, vasúti pályaudvarok, hidak, alagutak, forgalomirányító központok is áldozatul eshetnek. ${ }^{28}$ Ezeknek a létfontosságú rendszerelemeknek a sérülése a gazdaság, a társadalom életében rendkívül súlyos zavarokat okozna, ezért ezek kiemelt védelme elsődleges feladat.

\section{Összegzés}

Felgyorsult világunkban, a 21. században az egyik legfontosabb - vagy talán a legfontosabb - tényező az idő. A személyeknek és áruknak a világ egyik pontjáról a másikra történő minél rövidebb idő alatt és minél egyszerübb módon történő eljutása általános igénnyé és elvárássá vált. Az állam, a társadalom, a gazdaság mindennapi múködése elképzelhetetlen a közlekedési rendszerek egyes rendszerelemeinek igénybevétele nélkül. A közlekedésnek ezért kiemelt jelentősége van az ország gazdasági, társadalmi fejlődésében, a más országokkal történő kapcsolattartásban, továbbá az EU-tagságunkból, valamint a NATO-tagságunkból eredő kötelezettségek teljesítésében is. Tovább fokozza az ország közlekedési rendszerének jelentőségét, hogy Magyarország közlekedési létesítményei és közlekedési ellenőrzőrendszerei - az ország tranzit helyzete miatt - Európa közlekedési hálózatának központi és kritikus jelentőségü részei, amelyeken keresztül a kontinens minden fő irányában haladnak a személyek,

\footnotetext{
Teknős László - Endrődi István: A szélsőséges időjárás hatása a magyarországi közlekedési alrendszerekre - kiemelten a közút és vasút alágazatokra, in: Horváth Attila - Bányász Péter - Orbók Ákos (szerk.), Fejezetek a létfontosságú közlekedési rendszerelemek védelmének aktuális kérdéseiről, Nemzeti Közszolgálati Egyetem, Budapest, 2014, 81-97.

27 1035/2012. (II. 21.) Korm. határozat Magyarország Nemzeti Biztonsági Stratégiájáról 1. melléklet 29. pont. http://njt. hu/cgi_bin/njt_doc.cgi?docid=146225.213089 (Letöltve: 2019. 05. 15.)

28 Horváth (2014): i. m. 10.
} 
az áruk és a szolgáltatások. ${ }^{29}$ Mindezek alapján látható, hogy a közlekedés szerepe napjainkban soha nem látott mértékben felértékelődött, stratégiai fontosságúvá vált.

Ahogy a mindennapok - rendes - müködése, úgy a normál, mindennapi müködéstöl eltérő rendkívüli helyzetek kezelése sem képzelhető el a közlekedés müködőképes rendszerelemei nélkül. A rendkívüli helyzetek kezelésére hivatott védelmi igazgatás rendszere és a közlekedés rendszere számos ponton összekapcsolódnak. Ez a kapcsolat kiterjed az ország függetlenségének, az állampolgárok életének, egészségének, anyagi javainak védelmével kapcsolatos területekre is. A védelmi igazgatás e területek védelme és az ezzel összefüggő feladatok végrehajtása érdekében bevezetett rendkívüli intézkedéseket a közlekedési hálózatok és objektumainak igénybevétele nélkül nem lenne képes megvalósítani. A különböző veszélyekkel, rendkívüli helyzetekkel szembeni hatékony, zökkenőmentes és gyors fellépésnek, a szükséges honvédelmi, katasztrófavédelmi, rendvédelmi stb. feladatok eredményes ellátásának nélkülözhetetlen feltétele a müködőképes közlekedési rendszer megléte. A közlekedési alrendszerek mütárgyai, létfontosságú rendszerelemei rendkívül sérülékenyek a természeti és civilizációs katasztrófákkal, veszélyforrásokkal szemben, nagy kiterjedésük miatt könnyen és eredményesen támadhatók, rombolhatók. Védelmük alapvető érdek egy adott ország számára, így a hazai közlekedési rendszer müködőképességének fenntartása a védelmi igazgatás számára is kiemelkedő fontossággal bír. Ezek a kapcsolódási pontok rámutatnak arra, hogy a két, rendkívül komplex rendszer, illetve annak elemei egymással jelentős mértékü kölcsönhatásban állnak.

Az általam végrehajtott elemzések alapján az is kijelenthetö, hogy a közlekedési alágazatok nem azonos súllyal jelennek meg a védelmi igazgatás feladatrendszerében. A különböző, normál állapottól eltérő feladatok végrehajtása során döntően a közúti és a vasúti alágazat kapacitásait vesszük igénybe, ahol az egyik legnagyobb kihívás a kiesett kapacitások helyettesítése, a megfelelő tartalékkapacitások már békeidőszakban történő biztosítása. Ebből adódóan megítélésem szerint a védelmi igazgatás rendszerének nemcsak igénybevevőként kell jelen lennie a közlekedési folyamatokban, hanem már a hálózatok, kapacitások kiépítése, a szükséges tartalékok képzése során követelménytámasztóként is célszerü megjelennie. Ennek megvalósításához indokolt a jövőben a két rendszer szereplői között az együttmüködés, az információáramlás fokozása, amelynek során a védelmi bizottságok nagymértékű szerepvállalása is megfontolást érdemel.

\section{Felhasznált irodalom}

Baán Mihály - Bors István - Csiffáry Tamás - Hári László - Kocsis Lajos - Szentes László: Magyarország védelmi igazgatása a közigazgatás új környezetében, Zrínyi Kiadó, Budapest, 2014, www.kormany.hu/download/9/68/20000/Magyarorszag_ Vedelmi_lgazgatasa_a_Kozigazgatas_Uj_Kornyezeteben_2014_n.pdf\#!DocumentBrowse (Letöltve: 2019. 04. 24.)

29 Nemzeti Közlekedési Stratégia, Helyzetelemzés, 2014, 103.www.kormany.hu/download/6/3f/51000/01_NKS_Helyzetelemzes.pdf (Letöltve: 2019. 04. 24.) 
Babos Tibor - Beregi Alexandra Lilla: A védelemgazdaság biztonságpolitikai összefüggései napjainkban, Hadmérnök, 12 (2018/3) 339-352. www.hadmernok. hu/183_25_babos.pdf (Letöltve: 2019. 05. 13.)

Horváth Attila: Nyilvánosság és térjellemzők a létfontosságú rendszerelemek védelmében, in: Horváth Attila - Bányász Péter - Orbók Ákos (szerk.), Fejezetek a létfontosságú közlekedési rendszerelemek védelmének aktuális kérdéseiről, Nemzeti Közszolgálati Egyetem, Budapest, 2014, 7-26. DOI: https://doi.org/10.17047/ HADTUD.2016.26.E.189

Kövesné Gilicze Éva - Havas Péter - Mészáros Péter - Mándoki Péter - Debreczeni Gábor: Közlekedés és társadalom, BME, Budapest, 2010.

Szászi Gábor: Nagyfolyami vasúti hidak, mint közlekedési létfontosságú rendszerelemek, in: Horváth Attila - Bányász Péter - Orbók Ákos (szerk.), Fejezetek a létfontosságú közlekedési rendszerelemek védelmének aktuális kérdéseiről, Nemzeti Közszolgálati Egyetem, Budapest, 2014, 27-46.

Szászi Gábor: A vasúti hálózati infrastruktúrával szemben támasztott újszerủ védelmi követelmények kutatása, a továbbfejlesztés feltételrendszerének vizsgálata, Doktori (PhD) értekezés, Nemzeti Közszolgálati Egyetem, 2013. DOI: https://doi. org/10.17625/NKE.2014.028

Teknős László - Endrődi István: A szélsőséges időjárás hatása a magyarországi közlekedési alrendszerekre - kiemelten a közút és vasút alágazatokra, in: Horváth Attila - Bányász Péter - Orbók Ákos (szerk.), Fejezetek a létfontosságú közlekedési rendszerelemek védelmének aktuális kérdéseiröl, Nemzeti Közszolgálati Egyetem, Budapest, 2014, 81-97.

\section{Internetes források}

A közlekedés fogalma, a közlekedési rendszer csoportosítása, a közlekedési alágazatok kategorizálási lehetöségei, https://ko.sze.hu/catdoc/list/cat/7086/id/7106/m/4974 (Letöltve: 2019. 04. 30.)

Nemzeti Közlekedési Stratégia, www.kormany.hu/download/6/3f/51000/01_NKS_ Helyzetelemzes.pdf (Letöltve: 2019. 04. 24.)

A védelmi igazgatás fogalmában bekövetkezett módosulás indokolása, www.parlament.hu/irom41/03291/03291.pdf (Letöltve: 2019. 04. 25.)

\section{Jogi források}

1997. évi CLIV. törvény az egészségügyröl

2007. LXXX. törvény a menedékjogról

2011. évi CXIII. törvény (Hvt.) a honvédelemröl és a Magyar Honvédségről, valamint a különleges jogrendben bevezethető intézkedésekről

2011. évi CXXVIII. törvény a katasztrófavédelemről és a hozzá kapcsolódó egyes törvények módosításáról 
2012. évi CLXVI. törvény a létfontosságú rendszerek és létesítmények azonositásáról, kijelöléséről és védelméröl

234/2011. (XI. 10.) Korm. rendelet a katasztrófavédelemről és a hozzá kapcsolódó egyes törvények módosításáról szóló 2011. évi CXXVIII. törvény végrehajtásáról

290/2011. (XII. 22.) Korm. rendelet a honvédelemről és a Magyar Honvédségröl, valamint a különleges jogrendben bevezethető intézkedésekről szóló 2011. évi CXIII. törvény egyes rendelkezéseinek végrehajtásáról

1035/2012. (II. 21.) Korm. határozat Magyarország Nemzeti Biztonsági Stratégiájáról, http://njt.hu/cgi_bin/njt_doc.cgi?docid=146225.213089 (Letöltve. 2019. 05. 15.) 